\title{
Kemampuan Literasi Matematika: Kaitannya dengan Kemampuan Pemecahan Masalah
}

\author{
Ernika Samosir ${ }^{1, a)}$, Makmuri $^{2, \text { b) }}$, Tian Abdul Aziz ${ }^{3, c)}$ \\ ${ }^{1234}$ Universitas Negeri Jakarta \\ Email penulis: a)ernika.samosir@gmail.com, ${ }^{\text {b) }}$ makmuri@unj.ac.id, ${ }^{c}$ tian_aziz@unj.ac.id
}

\begin{abstract}
Mathematical literacy and problem-solving skills are very important skills in Mathematics education. Mathematical literacy is conceptually related to problem-solving skills. The purpose of writing this article is to examine the definition of mathematical literacy and problem-solving skills based on the literature and examine the relationship between the two mathematical abilities. The method in writing this article is using the literature study method. Data collection is done by reviewing articles, conference papers, and related books. From the initial 40 articles, there were only 32 articles that met the criteria, namely those published in the last 10 years and also indexed by Sinta or Scopus. From the results of the study, it was concluded that problem-solving skills are a component of competency in mathematical literacy. So that the existence of problem-solving skills in individuals will affect the ability of mathematical literacy skills.
\end{abstract}

Keywords: Literacy, Mathematical Literacy, PISA, Problem-solving Skills

\begin{abstract}
Abstrak
Kemampuan literasi matematika dan kemampuan pemecahan masalah merupakan kemampuan yang sangat penting dalam pendidikan Matematika. Literasi matematika secara konseptual memiliki keterkaitan dengan kemampuan pemecahan masalah. Tujuan penulisan artikel ini yaitu untuk mengkaji defenisi literasi matematika dan kemampuan pemecahan masalah berdasarkan literatur dan mengkaji keterkaitan dari kedua kemampuan matematis tersebut. Metode dalam penulisan artikel ini yaitu menggunakan metode studi literatur. Pengumpulan data dilakukan dengan mengkaji artikel, makalah konferensi dan juga buku yang terkait. Dari 40 artikel awal, hanya ada 32 artikel yang sesuai kriteria yaitu terbitan 10 tahun terakhir dan juga terindeks Sinta atau Scopus. Dari hasil kajian, disimpulkan bahwa kemampuan pemecahan masalah merupakan komponen kompetensi dalam literasi matematika. Sehingga keberadaan kemampuan pemecahan masalah dalam individu akan mempengaruhi kemampuan literasi matematika.
\end{abstract}

Kata kunci: Literasi, Literasi Matematika, PISA, Kemampuan Pemecahan Masalah

Copyright (c) 2022 Samosir, Makmuri, Aziz

$\triangle$ Corresponding author:

Email Address: ernika.samosir@gmail.com

Received 22 Januari 2022, Accepted 23 Februari 2022, Published 24 Februari 2022

https://doi.org/10.21009/jrpmj.v4i1.23026

\section{PENDAHULUAN}

Menjadi apa kelak seorang siswa akan sangat dipengaruhi oleh bekal berupa skill atau kompetensi apa yang telah dikuasainya melalui Pendidikan yang ditempuhya. Sistem Pendidikan akan menjadi perhatian dari setiap pihak terutama pemerintah. Sehingga untuk memantau bagaimana kinerja sistem pendidikan, keterlibatan Indonesia dalam berbagai studi komparatif internasional menjadi suatu pilihan yang mana PISA (Program for International Student Assessment) menjadi salah satu diantaranya. Melalui PISA, pemerintah bisa melihat bagaimana gambaran sistem pendidikan, 
termasuk bagaimana kebermanfaatan kompetensi yang dimiliki masyarakat. Hal ini sejalan dengan tujuan PISA yaitu untuk mengukur seberapa baik kesiapan siswa di sekolah dalam menerapkan apa yang telah mereka pelajari untuk menganalisis dan bernalar saat mereka harus menafsirkan dan memecahkan masalah dalam berbagai situasi yang dihadapi dalam hidup (Stacey, 2011). Kemampuan literasi matematika menjadi salah satu perhatian khusus yang dinilai melalui survei PISA.

Banyak kompetensi yang bisa dilatih ataupun dipelajari melalui proses pembelajaran matematika. Kompetensi tersebut akan menjadi berarti jika suatu individu dapat memanfaatkannya dalam menyelesaikan suatu masalah baik untuk kepentingan dirinya sendiri, ataupun sebagai partisipasi dalam lingkungannya sebagai warga masyarakat. Apalagi sekarang ini, semua orang harus memiliki kompetensi dan keterampilan tingkat lanjut, bukan sekedar karena alasan ekonomi tetapi juga untuk partisipasi sosial (Schleicher, 2019). Dalam menyelesaikan permasalahan kehidupan sehari-hari yang tentunya berkaitan dengan konteks tertentu, tidak cukup hanya menggunakan kemampuan matematis yang sekedar mampu berhitung atau mengoperasikan operasi matematika, tetapi diperlukan kemampuan yang melibatkan pengetahuan matematika secara luas seperti kemampuan literasi matematika (De Lange, 2003; Fadillah \& Ni'mah, 2019). Orang dengan kemampuan literasi matematika tidak sekedar memahami matematika, tetapi juga dapat menggunakannya untuk menyelesaikan masalah sehari-hari (Muzaki \& Masjudin, 2019). Partisipasi dalam masyarakat dan pekerjaan di dunia yang kaya akan informasi ini memerlukan literasi matematika yang luas (Stacey, 2011).

Literasi matematika berkaitan dengan pengetahuan siswa berupa kemampuan untuk mengambil dan menggunakan kemampuan matematisnya dari kelas ke pengalaman kehidupan keseharian mereka dan bagaimana suatu situasi dipahami dengan melibatkan matematika (Sumirattana et al., 2017). Literasi matematika juga diartikan sebagai kemampuan seseorang dalam merumuskan, menggunakan dan menafsirkan dalam berbagai konteks (Mansur, 2018). Siswa dengan kemampuan literasi matematika akan mampu membuat perkiraan, menginterpretasikan data, memecahkan masalah sehari-hari, dan mampu menampilkan simpulan masalah dalam bentuk grafik dan geometris dan paham bagaimana mengomunikasikannya (Ojose, 2011). Dengan kata lain, kemampuan literasi matematika menjadi kemampuan yang memiliki peranan penting untuk bisa berhadapan langsung dengan permasalahan nyata.

Untuk meningkatkan kemampuan ini, maka diperlukan usaha untuk mengembangkannya dalam proses pembelajaran. Untuk memahami karakteristik model atau strategi pembelajaran seperti apa yang paling sesuai untuk meningkatkan kemampuan literasi matematika, maka perlu dilakukan penelitian untuk menganalisis profil kemampuan literasi matematika siswa dan juga kaitannya dengan variabel lain yang memiliki potensi untuk mengembangkannya. Kemudian potret kemampuan literasi matematika selanjutnya bisa digunakan sebagai pedoman dalam menyusun kegiatan pembelajaran (Rusmining, 2017). Pemahaman guru terhadap aspek dan juga proses evaluasi literasi matematika merupakan hal utama yang harus dikembangkan secara terstruktur dan sistematis agar isi, proses, dan 
konteks dalam literasi matematika menjadi dasar bagi pengembangan pelaksanaan pembelajaran matematika (Umbara \& Suryadi, 2019). Analisis kemampuan literasi matematika bertujuan untuk berusaha mendeskripsikan secara detail bagaimana proses kemampuan literasi matematika muncul baik saat siswa diposisikan dalam menyelesaikan suatu masalah dan kemampuan apa aja yang mempengaruhinya.

Penelitian untuk mendeskripsikan kemampuan literasi siswa telah banyak dilakukan oleh peneliti-peneliti sebelumnya. Diantaranya ada analisis kemampuan literasi berdasarkan Kemampuan Awal Matematis (KAM) yang dilakukan oleh Muzaki and Masjudin (2019) pada siswa kelas XI. Hasil penelitian ini menyimpulkan bahwa baik siswa yang tergolong KAM tinggi, sedang, ataupun rendah, semuanya masih memiliki kemampuan literasi rendah. Selanjutnya ada juga Syawahid dan Putrawangsa (2017) yang menganalisis kemampuan literasi matematika siswa kelas VIII ditinjau dari gaya belajar. Hasil dari penelitian ini menyimpulkan bahwa dalam pemilihan strategi pembelajaran untuk mengembangkan kemampuan literasi matematika dalam proses pembelajaran sebaiknya mempertimbangkan gaya belajar siswa. Kemudian Fadillah and Ni'mah (2019) melakukan analisis literasi matematika siswa dalam memecahkan soal matematika PISA secara khusus untuk konten Change and Relationship. Berikutnya ada juga analisis kemampuan literasi matematika siswa kelas $\mathrm{X}$ dalam meyelesaikan soal matematika model PISA menggunakan konteks Palembang yang diteliti oleh Lestari dan Putri (2020). Kesimpulan dalam penelitian ini mengatakan bahwa pemilihan konteks akan sangat mempengaruhi kemampuan literasi matematika.

Berdasarkan penelitian terdahulu yang dipaparkan di atas, belum ada kajian literatur yang secara khusus membahas bagaimana kemampuan literasi matematika dengan kemampuan pemecahan masalah saling terkait. Dalam penelitian eksploratif yang dilakukan oleh Oktaviyanthi dan Agus (2019) menyebutkan bahwa keberadaan kemampuan pemecahan masalah dalam diri individu dapat mempengaruhi kemampuan fundamental matematisnya. Dengan kata lain, keberadaan kemampuan pemecahan masalah siswa akan berkontribusi pada seberapa literate siswa dalam menyelesaikan suatu permasalahan dengan konsep matematika. Sehingga dalam literatur ini, bagaimana individu menyeselaikan suatu masalah, indikator pemecahan masalah yang dilakukannya dapat dikategorikan berdasarkan proses literasi matematis. Dalam artikel ini, penulis akan mengkaji berbagai literatur untuk membahas bagaimana kemampuan literasi matematika dengan kemampuan pemecahan masalah saling terkait baik secara konseptual atau berdasarkan proses.

Sehingga yang menjadi rumusan masalah dalam tulisan ini yaitu: 1) Bagaimana literatur mendefenisikan literasi matematika dan kemampuan pemecahan masalah? 2) Bagaimana keterkaitan keduanya dalam berbagai literatur? Pertanyaan-pertanyaan tersebut akan dibahas dalam tulisan ini. Maka tujuan dari artikel ini adalah untuk mengkaji berbagai literatur dalam mendefenisikan kedua kemampuan matematis ini dan untuk melihat bagaimana keterkaitan literasi matematika dengan kemampuan pemecahan masalah dalam berbagai literatur. Hasil kajian literatur ini akan berguna dalam hal memperdalam teori terkait kemampuan literasi matematika. Dengan memahami bagaimana 
keterkaitan dari kedua kemampuan matematis ini, akan bermuara pada peningkatan kemampuan literasi matematika siswa di kelas. Berdasarkan kajian literatur ini juga bisa ditindaklanjuti dengan penelitian analisis kemampuan literasi matematika berdasarkan kemampuan pemecahan masalah.

\section{METODE}

Artikel ini ditulis menggunakan metode studi literatur dengan mencari referensi teori yang relevan dengan permasalahan yang dibahas. Literatur yang digunakan terdiri dari buku, artikel, dan juga beberapa makalah konferensi. Pencarian artikel dilakukan dengan mesin pencari Google Schoolar dan juga database Science Direct dan ERIC dengan kata kunci "Literasi Matematika", "Mathematical Literacy", "Kemampuan Pemecahan Masalah", dan "Problem Solving Skills." Pencarian tambahan juga dilakukan berdasarkan Daftar Pustaka yang ada pada artikel yang diulas untuk mengetahui informasi lebih lanjut.

Dari 40 artikel yang diunduh menggunakan kata kunci di atas, hanya 32 artikel yang sesuai kriteria. Kriteria yang digunakan untuk memilih artikel tersebut yaitu artikel yang digunakan adalah artikel 10 tahun terakhir. Akan tetapi ada beberapa artikel utama dari variabel terkait yang tetap digunakan meskipun terbitan di atas 10 tahun terakhir. Selain itu artikel yang digunakan juga mempertimbangkan indeks dari setiap jurnal, yaitu agar artikel yang dikaji adalah artikel-artikel yang terindeks Sinta dan juga Scopus. Hal ini bertujuan agar sumber-sumber yang digunakan dianggap valid, relevan, dan dapat diandalkan karena kualitas akademiknya yang tinggi. Untuk memeriksa indeks dari setiap jurnal dilakukan dengan memeriksa jurnal tersebut di portal Sinta dan juga Scimago. Selain artikel terdapat 2 buku dan 3 makalah konferensi yang juga digunakan sebagai pendukung untuk melengkapi informasi yang tidak dapat ditemukan dalam artikel sebagai pengayaan. Setelah melakukan semua tahapan tersebut, peneliti melakukan anotasi untuk menemukan informasi yang berkaitan dengan rumusan masalah artikel ini dan informasi tersebut akan dianalisis.

Analisis data dilakukan dengan analisis deskriptif. Proses analisis data yang dilakukan yaitu mereduksi data, menyajikan data, kemudian menarik kesimpulan. Tahap mereduksi data dilakukan dengan melakukan anotasi terhadap artikel untuk menemukan informasi yang diperlukan sesuai dengan rumusan masalah. Selanjutnya data disajikan dalam tabulasi untuk mempermudah penulis dalam menarik kesimpulan. Kemudian menarik kesimpulan untuk menjawab pertanyaan pada rumusan masalah.

\section{HASIL DAN PEMBAHASAN}

Kemampuan Literasi Matematika. Pada bagian pendahuluan sudah dipaparkan mengapa kemampuan Literasi matematika menjadi kemampuan yang sangat penting dan harus dikembangkan dalam proses pembelajaran matematika. Bahkan Stacey (2011) juga menyebutkan jika literasi 
matematika dianggap sebagai hasil yang berharga yang harus dikembangkan di sekolah, maka kemampuan ini juga harus terwakili dengan baik dalam tujuan dan implementasi kurikulum. Dengan kemampuan literasi matematika yang baik, akan membantu seseorang mengenali peran matematika dalam kehidupan dan membuat penilaian dan keputusan secara rasional dan logis yang diperlukan oleh warga negara yang konstruktif, berpartisipasi aktif, dan juga reflektif (Syawahid \& Putrawangsa, 2017).

Literasi sendiri didefinisikan sebagai pengetahuan dan keterampilan yang diperlukan untuk memahami dan menggunakan informasi yang tersimpan dalam suatu teks atau format tertulis lainnya (Umbara \& Suryadi, 2019). Literasi juga diartikan sebagai kapabilitas hidup dan merupakan fondasi Pendidikan yang di dalamnya termasuk keterampilan dalam memahami, membaca, menulis dan berhitung (Mahdiansyah \& Rahmawati, 2014). Selanjutnya defenisi literasi matematika berdasarkan beberapa literatur yang dikaji dalam tulisan ini ditampilkan dalam tabel 1.

Tabel 1. Defenisi Literasi Matematika dalam Beberapa Literatur

\begin{tabular}{|c|c|}
\hline Referensi & Defenisi \\
\hline (Edo dkk., 2013) & $\begin{array}{l}\text { Literasi matematika yang dinilai dalam PISA yaitu kinerja } \\
\text { siswa dalam menganalisis, bernalar, dan mengkomunikasikan } \\
\text { gagasannya secara efektif sebagai suatu formula, untuk } \\
\text { memecahkan dan memodelkan permasalahan matematika } \\
\text { dalam berbagai situasi. }\end{array}$ \\
\hline (Wijaya, 2016) & $\begin{array}{l}\text { Literasi matematika merupakan kemampuan untuk } \\
\text { menggunakan pemahaman matematis yang sudah dimilikinya } \\
\text { ke dalam permasalahan kehidupan sehari-hari. }\end{array}$ \\
\hline $\begin{array}{l}\text { (Sumirattana dkk., } \\
\text { 2017) }\end{array}$ & $\begin{array}{l}\text { Literasi matematika adalah pengetahuan dan kemampuan siswa } \\
\text { untuk mengambil dan menggunakan pengetahuan dan } \\
\text { keterampilan matematika yang sudah diperoleh mereka dari } \\
\text { kelas ke pengalaman kehidupan nyata serta kemampuan } \\
\text { memahami situasi yang melibatkan matematika. }\end{array}$ \\
\hline $\begin{array}{l}\text { (Syawahid and } \\
\text { Putrawangsa, } \\
\text { 2017) }\end{array}$ & $\begin{array}{l}\text { Literasi matematika yaitu kemampuan siswa untuk } \\
\text { merumuskan, menggunakan, dan menginterpretasi matematika } \\
\text { dalam berbagai konteks. }\end{array}$ \\
\hline (Mansur, 2018) & $\begin{array}{l}\text { Literasi matematika diartikan sebagai kapasitas seseorang } \\
\text { untuk merumuskan suatu masalah, kemudian menggunakan } \\
\text { pengetahuan matematika dalam penyelesaiannya, dan juga } \\
\text { diharapkan bisa menafsirkannya dalam berbagai situasi. }\end{array}$ \\
\hline
\end{tabular}

Beberapa defenisi literasi matematika dari berbagai literatur yang dipaparkan pada tabel 1 di atas secara umum memiliki kesamaan dan secara konseptual semuanya mengacu pada defenisi literasi matematika PISA. Dapat disimpulkan bahwa literasi matematika merupakan kapasitas seseorang dalam menggunakan berbagai kompetensi matematis yang sudah diperolehnya di kelas untuk memecahkan masalah sehari-hari dalam berbagai situasi. Berbagai kemampuan matematis yang dimaksud di sini merujuk pada Rusmining (2017) yaitu bisa berupa kemampuan komunikasi, matematisasi, representasi, penalaran, menjabarkan strategi untuk memecahkan masalah, 
menggunakan simbol dan operasi, dan menggunakan alat matematika. Bisa dikatakan kemampuan literasi matematika mencakup banyak kemampuan matematis lainnya dalam prosesnya.

Dalam pendefenisian literasi matematika, terdapat penekanan bahwa kemampuan ini tidaklah terbatas pada aspek kuantitatif matematika terapan saja, tetapi dapat melibatkan pengetahuan matematika dalam arti yang lebih luas dan komprehensif dari beberapa bagian yaitu literasi spasial, numerasi, dan literasi kuantitatif (Umbara \& Suryadi, 2019). Dalam pendefenisian literasi matematika, ada juga penekanan bahwa kemampuan ini sangat penting agar seseorang dapat mengaplikasikan pemahaman matematika yang sudah dimilikinya ke dalam permasalahan kehidupan sehari-hari (Syawahid \& Putrawangsa, 2017; Wijaya, 2016). Permasalahan kehidupan sehari-hari yang dimaksud di sini selanjutnya akan disajikan dalam tugas matematis berbasis konteks sebagai alat untuk mengembangkan kemampuan ini. Dengan kata lain keterampilan guru dalam menyajikan suatu masalah dalam suatu konteks menjadi bagian terpenting dalam melatih kemampuan ini.

Literasi dalam konteks memberikan komunikasi yang baik dan tentu akan membuat lebih mudah dipahami. Konteks dalam penilaian literasi merupakan bagian terpenting, dan akan mempengaruhi hasil penilaian (Mahdiansyah \& Rahmawati, 2014). Beberapa konteks yang digunakan dalam literasi matematika, yaitu personal (konteks yang berkaitan dengan kehidupan pribadi suatu individu dan keluarga dalam kesehariannya), occupational (konteks yang berkaitan dengan dunia kerja), societal (konteks yang berkaitan dengan kehidupan sosial dalam komunitas baik lokal, nasional ataupun global) dan scientific (konteks yang berkaitan denggan penerapan matematika dan sains dalam ilmu pengetahuan dan teknologi) (Edo dkk., 2013; Mahdiansyah \& Rahmawati, 2014).

Saat suatu masalah disajikan dalam konteks, siswa dituntut untuk bisa mengidentifikasi dan memilih informasi yang paling relevan (Wijaya, 2016). Dalam hal ini literasi matematika memiliki kontribusi penting dalam menilai validitas suatu informasi yang diterima oleh seseorang (Zahid, 2020). Proses memverifikasi solusi yang dilakukan dalam proses literasi matematika juga akan memberi struktur pada penalaran siswa (Hillman, 2014). Jika kompetensi matematis seseorang tidak cukup luas, sekalipun suatu masalah dapat diselesaikan, dalam hal ini tanpa kemampuan literasi matematis maka solusi yang ditawarkan mungkin saja bukan yang paling relevan. Bisa disimpulkan dengan kemampuan literasi matematika, seseorang dapat berhasil memecahkan suatu masalah secara efektif.

Salah satu usaha untuk melatih kemampuan literasi matematika siswa, yaitu membiasakan siswa untuk berlatih dengan soal-soal yang berbasis argumentasi yaitu melalui soal-soal PISA (Mansur, 2018). Literasi Matematika dalam PISA berfokus pada kapasitas siswa dalam menganalisis, menalar dan mengkomunikasikan ide secara efektif sebagai formula, memecahkan dan melakukan pemisalan pada permasalahan matematika di setiap situasi (Edo dkk., 2013). Hal ini juga dikarenakan, soal-soal PISA disajikan dalam konteks dan ini merupakan bagian terpenting dalam menilai literasi matematika seperti yang dijelaskan pada pembahasan sebelumnya. Untuk bisa mendapatkan penilaian yang lebih baik, konteks yang digunakan dalam masalah untuk mengukur kemampuan literasi 
matematiksa siswa dengan pendekatan yang familiar dengan konteks Indonesia (Mahdiansyah \& Rahmawati, 2014).

Penilaian literasi matematika pada PISA terdiri atas 6 level (Prabawati, 2018). Literasi matematis level 1 dan 2 dikategorikan sebagai skala bawah, yaitu untuk mengukur kompetensi reproduksi. Literasi matematis level 3 dan 4 dikategorikan pada skala menengah, yaitu untuk mengukur kompetensi koneksi. Terakhir, literasi level 5 dan 6 dikategorikan sebagai skala tinggi, yaitu untuk mengukur kompetensi refleksi (Fadillah \& Ni'mah, 2019). Pengkategorian tinggi rendahnya kemampuan literasi ini disesuaikan dengan pengakategorian level yang dijelaskan sebelumnya.

Kemampuan Pemecahan Masalah. Kemampuan pemecahan masalah telah menjadi kemampuan matematis yang selalu menarik untuk dibahas, dan telah menjadi sasaran utama tujuan Pendidikan Matematika dari tahun ke tahun. Bahkan dikatakan bahwa Matematika merupakan salah satu bidang studi yang memiliki peranan penting dalam meningkatkan kemampuan ini (Scherer \& Beckmann, 2014). Kemampuan pemecahan masalah matematika sebagai aspek penting dan menjadi kebutuhan dalam kurikulum matematika di seluruh dunia (Liljedahl dkk., 2016). Oleh sebab itu sangat menarik untuk dibahas bagaimana kemampuan ini bisa ditingkatkan dalam proses pembelajaran. Kemampuan pemecahan masalah adalah keterampilan penting yang harus dibantu oleh semua guru matematika untuk membantu siswa mengembangkan keterampilan matematikanya (Hensberry \& Jacobbe, 2012). Untuk mendefenisikan apa itu kemampuan pemecahan masalah, tentu kita akan berangkat dari pengertian apa itu masalah.

Tidak semua soal matematika bisa dianggap sebagai masalah. Masalah dalam matematika yang benar-benar bisa dianggap sebagai masalah yaitu soal yang signifikan memiliki potensi untuk memberikan konteks intelektual untuk perkembangan matematika siswa (Novita, 2012), dan dibutuhkan wawasan kreatif dalam memecahkannya (Liljedahl dkk., 2016). Dengan adanya masalah, maka ada rintangan di mana seseorang yang hendak memecahkannya tidak langsung bisa melihat bagaimana mengatasinya. Tentu ini akan bergantung pada sejauh mana keterampilan konsep dan konten yang dimiliki oleh si pemecah masalah tersebut. Sehingga pada dasarnya, masalah bagi seseorang belum tentu menjadi masalah bagi orang lain (Novita, 2012).

Dengan adanya masalah, siswa akan berada pada situasi berjuang dalam proses pemecahan masalah yang tentunya akan membutuhkan berbagai keterampilan matematis. Pemecahan masalah merupakan usaha mencari jalan keluar dari kesulitan (yang selanjutnya akan disebut suatu masalah) sehingga bisa sampai pada tujuan yang mungkin tidak mudah dapat dicapai dan ini bisa disebabkan karena kesalahan proses, kesalahan berpikir, pembelajaran, ingatan, transfer, persepsi dan motivasi (Rohmah \& Sutiarso, 2018). Selanjutnya defenisi kemampuan pemecahan masalah berdasarkan beberapa literatur yang dikaji dalam tulisan ini ditampilkan dalam tabel 2.

Tabel 2. Defenisi Kemampuan Pemecahan Masalah dalam Beberapa Literatur 


\begin{tabular}{ll}
\hline Referensi & Defenisi \\
\hline (Jonassen, 2010) & $\begin{array}{l}\text { Kemampuan pemecahan masalah merupakan kemampuan } \\
\text { untuk memecahkan masalah baik masalah lintas disiplin atau } \\
\text { masalah dunia nyata dengan menerapkan keterampilan kognitif } \\
\text { seperti penalaran dan pemikiran logis. }\end{array}$ \\
\hline Kemampuan pemecahan masalah mencakup keterampilan \\
untuk mengidentifkasi masalah, merencanakan masalah, \\
memantau kemajuan saat masalah ditangani dan kemudian \\
meninjau solusi untuk masalah.
\end{tabular}

Dalam mendefenisikan kemampuan pemecahan masalah, ada penekanan bahwa masalah yang dimaksud haruslah berkaitan dengan dunia nyata atau bisa berupa lintas displin (Jonassen, 2010), dan keterampilan kognitif yang terlibat di dalamnya yaitu penalaran dan pemikiran logis (Jonassen, 2010; Rohmah \& Sutiarso, 2018). Pendapat lain mengatakan, agar kemampuan pemecahan masalah dapat dievaluasi, maka masalah yang diberikan haruslah masalah nonrutin (Arfiana \& Wijaya, 2018; Novita, 2012; Utami \& Wutsqa, 2017). Akan tetapi, kemampuan pemecahan masalah bukanlah kemampuan yang dapat diperoleh dalam waktu yang singkat. Diperlukan proses paralel untuk bisa sampai pada keterampilan ini (Van Merrienboer, 2013). Sehingga dalam pendefenisiannya, berbeda dengan yang dijelaskan pada referensi sebelumnya, bahwa untuk melatih kemampuan pemecahan masalah, masalah rutin juga dimasukkan (Rohmah \& Sutiarso, 2018; Van Merrienboer, 2013). Hanya saja dalam literatur tersebut juga dijelaskan bahwa masalah rutin dapat dilakukan secara otomatis sebagai proses latihan hingga siswa memiliki pengalaman lebih untuk bisa naik ke level masalah nonrutin yang memerlukan kemampuan kognitif lebih (Rohmah \& Sutiarso, 2018; Van Merrienboer, 2013). Dapat disimpulkan bahwa kemampuan pemecahan masalah adalah kapasitas keterampilan kognitif siswa dalam memecahkan suatu masalah yang menuntut kemampuan bernalar dan berlogika di dalam prosesnya.

Pemecahan masalah dapat dipandang dari berbagai sudut pandang diantaranya sebagai tujuan, metode ataupun keterampilan (Van Merrienboer, 2013). Dalam tulisan ini secara khusus penulis melihatnya sebagai keterampilan. Hal ini berkaitan dengan rumusan masalah yang hendak dikaji yaitu 
untuk melihat bagaimana kaitannya dengan literasi matematika. Hanya saja dari beberapa literatur yang dikaji, kemampuan ini akan bisa berkembang sebagai proses dalam kegiatan pemecahan masalah yang dilakukan siswa. Banyak keterampilan matematika yang terlibat dalam proses pemecahan masalah (Tambychik \& Meerah, 2010). Agar siswa dapat mentrasfer pengetahuan mereka secara efektif dari satu area aplikasi ke area lain, siswa memerlukan pengalaman memecahkan masalah dalam banyak situasi dan konteks yang berbeda (Ojose, 2011). Pemecahan masalah dalam matematika akan membantu siswa untuk mengalami bagaimana memecahkan masalah kehidupan sehari-hari dengan menerapkan pengetahuan dan keterampilan matematika mereka (Osman dkk., 2018). Kemampuan terukur yang diperlukan dalam proses pemecahan masalah inilah selanjutnya disebut sebagai kemampuan pemecahan masalah.

Ada beberapa langkah-langkah dalam pemecahan masalah menurut para ahli yang banyak diadopsi dalam beberapa penelitian. Langkah-langkah dalam proses pemecahan masalah yang paling umum dalam penelitian Pendidikan yaitu tahapan Polya. Pemecahan masalah tahapan Polya (Polya, 1973 dalam Arfiana and Wijaya, 2018), yaitu: (a) memahami masalah, (b) menyusun rencana, (c) melaksanakan rencana, (d) melihat ke belakang.

Kemampuan pemecahan masalah siswa tentunya dapat ditingkatkan dengan berbagai usaha, diantaranya dengan membiasakan mereka menyelesaikan masalah nonrutin (Utami \& Wutsqa, 2017), membiasakan siswa dalam menyelesaikan masalah yang menuntut kemampuan berpikir tingkat tinggi (Maharaj \& Wagh, 2016). Selain itu tugas pemecahan masalah matematika yang dirumuskan dalam tes PISA adalah salah satu dari tugas alternatif yang dapat digunakan untuk mengembangkan kemampuan pemecahan masalah siswa, karena soal-soal yang diberikan dalam tes ini adalah soal kontekstual dan nonrutin yang mengukur literasi matematika siwa (Novita, 2012). Masalah nonrutin yang dimaksud di sini yaitu tugas yang memerlukan pemikiran lebih lanjut karena prosedur/ algoritma tidak cukup jelas (Novita, 2012). Dengan kata lain, suatu masalah yang disajikan dalam suatu konteks seperti soal PISA dapat digunakan sebagai instrumen dalam menilai kemampuan literasi matematika siswa yang di dalam prosesnya juga bisa menilai kemampuan pemecahan masalah.

Keterkaitan antara Kemampuan Literasi Matematika dengan Kemampuan Pemecahan

Masalah. Setelah pada pembahasan sebelumnya telah dijelaskan masing-masing apa itu kemampuan literasi dan kemampuan pemecahan masalah matematika, maka pada bagian ketiga ini akan membahas bagaimana keterkaitan dari kedua kemampuan matematis tersebut. Ojose (2011) menyebutkan bahwa salah satu kompetensi yang sangat diperlukan agar seseorang melek (literate) matematika yaitu kemampuan pemecahan masalah. Dengan kata lain, kemampuan pemecahan masalah merupakan kompetensi penting yang harus dimiliki individu untuk meningkatkan kemampuan literasi matematikanya. Hal ini senada dengan apa yang disebutkan Oktaviyanthi dan Agus (2019) yang menyatakan bahwa keberadaan kemampuan pemecahan masalah pada seseorang akan berpengaruh pada kemampuan fundamental matematisnya dan juga akan berpengaruh pada kemampuan literasi matematisnya. Kemudian pertanyaan yang juga menarik untuk dibahas yaitu, 
apakah meningkatkan kemampuan pemecahan masalah sudah cukup untuk meningkatkan kemampuan literasi matematika?

Dalam analisis kemampuan literasi matematika yang dilakukan oleh Rusmining (2017) disebutkan jika salah satu kemampuan literasi matematika yang lebih banyak diukur dalam studi PISA yaitu kemampuan pemecahan masalah. Dengan kata lain, dalam studi PISA meskipun kompetensi matematis yang dinilai yaitu kemampuan literasi matematika, tapi di dalam prosesnya juga mencakup kemampuan pemecahan masalah. Atsnan dkk. (2018) menjelaskan bahwa yang merupakan fokus dari pengembangan literasi matematis siswa yaitu kompetensi pemecahan masalah dalam baik dalam bidang matematika dan juga sains yang berkaitan dengan permasalahan nyata. Menurut Atsnan dkk. (2018), membiasakan siswa dalam kegiatan pemecahan masalah dalam pembelajaran akan mempengaruhi kemampuan literasi matematika dari siswa tersebut. Kesimpulan ini tidak beda jauh dengan apa yang dijelaskan oleh Ojose (2011).

Penyebab rendahnya kemampuan literasi matematika dalam beberapa literatur dikaitkan dengan kemampuan pemecahan masalah. Muzaki and Masjudin (2019) memaparkan beberapa penyebab rendahnya kemampuan literasi matematika siswa, yaitu: kebiasaan siswa yang hanya dibiasakan mengerjakan soal-soal yang masih bersifat prosedural, siswa belum terbiasa dengan soalsoal yang membutuhkan pemikiran logis, kritis, dan solusi yang aplikatif. Dengan kata lain kemampuan pemecahan masalah siswa yang kurang terlatih menjadi penyebab rendahnya kemampuan literasi matematika.

Adapun komponen dalam Literasi Matematika (Sumirattana dkk., 2017) yaitu: a) pemahaman, yang terdiri dari pemahaman konseptual dan pemahaman prosedural. b) kompetensi, yang terdiri dari: kompetensi dalam memahami masalah, memilih pengetahuan yang relevan, menguraikan rencana penyelesaian, mempertimbangkan dan memecahkan masalah, serta memeriksa solusi. Dalam komponen kompetensi inilah kita bisa melihat banyak kompetensi matematis yang terlibat di dalamnya, dan salah satunyanya adalah pemecahan masalah. Sehingga ini bisa juga menjadi alasan mengapa Sumirattana dkk. (2017) menyebutkan bahwa konsep literasi matematika berkaitan erat dengan beberapa konsep lain yang dibahas dalam pendidikan matematika. Salah satu kompetensi dalam literasi matematika yaitu kemampuan dalam pemecahan masalah. Kemampuan matematis ini akan dikaji pada pembahasan berikutnya.

Berdasarkan defenisi dan juga tujuan dari kedua kemampuan matematis ini, mungkin ada beberapa penjelasan yang tumpang tindih yang menyiratkan bahwa ada kemungkinan dua arah. Yaitu kemampuan pemecahan masalah yang mempengaruhi kemampuan literasi matematika seseorang atau sebaliknya yaitu kemampuan literasi matematika akan mempengaruhi kemampuan pemecahan masalah. Berdasarkan penjelasan kemampuan literasi matematika pada pembahasan sebelumnya, secara eksplisit ada pengertian bahwa literasi matematika berkaitan dengan wawasan matematis yang cukup luas, sehingga seseorang dengan kemampuan literasi matematika yang baik diharapkan dapat memecahkan masalah matematika secara efektif dalam berbagai konteks. Tetapi pada pembahasan 
lebih lanjut juga dijelaskan bahwa salah satu komponen literasi matematika ada kompetensi yang juga berkaitan dengan kemampuan pemecahan masalah. Sehingga dalam artikel ini, penulis menyimpulkan keterkaitan kedua kemampuan matematis ini, yaitu kemampuan pemecahan masalah merupakan kompetensi yang harus dimiliki individu dalam meningkatkan kemampuan literasi matematikanya.

\section{KESIMPULAN}

Dapat disimpulkan bahwa jika seorang siswa dikatakan memiliki kemampuan literasi matematika yang tinggi, maka siswa tersebut mampu menganalisis, menalar, dan mengomunikasikan pengetahuan dan keterampilan matematika yang sudah dimilikinya secara efektif, serta mampu memecahkan dan menginterpretasilkan masalah matematika dalam berbagai situasi (Novita, 2012). Literasi matematika secara konseptual memiliki keterkaitan dengan kemampuan pemecahan masalah (Scherer \& Beckmann, 2014). Keterkaitan tersebut yaitu dalam komponen literasi matematika ada beberapa komponen kompetensi yang salah satunya adalah kemampuan pemecahan masalah. Kemampuan pemecahan masalah menjadi kemampuan dasar yang harus dimiliki oleh siswa agar maksimal dalam mengejarkan masalah matematika yang disajikan dalam konteks.

Kesimpulan ini berimplikasi bahwa kemampuan pemecahan masalah yang baik juga akan berpengaruh pada kemampuan literasi matematika yang baik. Untuk mengembangkan teori terkait implikasi ini, diperlukan penelitian lebih lanjut untuk menganalisis bagaimana kedua kemampuan ini saling berkaitan. Oleh sebab itu saran penelitian selanjutnya yaitu penelitian analisis kemampuan literasi matematika siswa berdasarkan kemampuan pemecahan masalah.

\section{UCAPAN TERIMA KASIH}

Terima kasih kepada dosen pembimbing saya, bapak Makmuri dan bapak Tian Abdul Aziz, yang sudah memberikan masukan akan penulisan artikel ini.

\section{DAFTAR PUSTAKA}

Arfiana, A., \& Wijaya, A. (2018). Problem solving skill of students of senior high schools and Islamic high schools in Tegal Regency in solving the problem of PISA based on Polya's stage. Jurnal Riset Pendidikan Matematika, 5(2), 211-222.

Atsnan, M. F., Gazali, R. Y., \& Nareki, M. L. (2018). Pengaruh pendekatan problem solving terhadap kemampuan representasi dan literasi matematis siswa. Jurnal Riset Pendidikan Matematika, 5(2), 135-146.

De Lange, J. (2003). Mathematics for Literacy. Quantitative Literacy: Why Numeracy Matters for Schools and Colleges, 75-89.

Edo, S. I., Hartono, Y., \& Putri, R. I. I. (2013). Investigating secondary school students' difficulties in modeling problems PISA-model level 5 and 6. Journal on Mathematics Education, 4(1), 41-58. https://doi.org/10.22342/jme.4.1.561.41-58 
Fadillah, A., \& Ni’mah. (2019). Analisis Literasi Matematika Siswa Dalam Memecahkan Soal Matematika PISA Konten Change and Relationship. Analisis Literasi Matematika Siswa Dalam Memecahkan Soal Matematika PISA Konten Change and Relationship, 3(2), 127-131.

Hensberry, K. K. R., \& Jacobbe, T. (2012). The effects of Polya's heuristic and diary writing on children's problem solving. Mathematics Education Research Journal, 24(1), 59-85. https://doi.org/10.1007/s13394-012-0034-7

Hillman, A. M. (2014). A literature review on disciplinary literacy: How do secondary teachers apprentice students into mathematical literacy? Journal of Adolescent \& Adult Literacy, 57(5), $397-406$.

Jonassen, D. H. (2010). Learning to solve problems: A handbook for designing problem-solving learning environments. Routledge.

Lestari, N., \& Putri, R. I. I. (2020). Using the Palembang's Local Context in PISA-Like Mathematics Problem for Analyze Mathematics Literacy Ability of Students. Jurnal Pendidikan Matematika, 14(2), 169-182. https://doi.org/10.22342/jpm.14.2.6708.169-182

Liljedahl, P., Santos-Trigo, M., Malaspina, U., \& Bruder, R. (2016). Problem solving in mathematics education. Springer Nature.

Maharaj, A., \& Wagh, V. (2016). Formulating tasks to develop HOTS for first-year calculus based on Brookhart abilities. South African Journal of Science, 112(11-12), 1-6. https://doi.org/10.17159/sajs.2016/20160139

Mahdiansyah, M., \& Rahmawati, R. (2014). Literasi matematika siswa pendidikan menengah: Analisis menggunakan desain tes internasional dengan konteks Indonesia. Jurnal Pendidikan Dan Kebudayaan, 20(4), 452-469.

Mansur, N. (2018). Melatih Literasi Matematika Siswa dengan Soal PISA. Prisma, 1, 140-144.

Muzaki, A., \& Masjudin, M. (2019). Analisis Kemampuan Literasi Matematis Siswa. Mosharafa: Jurnal Pendidikan Matematika, 8(3), 493-502.

Novita, R. (2012). Exploring Primary Student's Problem-Solving Ability by Doing Tasks Like PISA's Question. Indonesian Mathematical Society Journal on Mathematics Education, 3(2), 133-150.

Ojose, B. (2011). Mathematics literacy: Are we able to put the mathematics we learn into everyday use. Journal of Mathematics Education, 4(1), 89-100.

Oktaviyanthi, R., \& Agus, R. N. (2019). Eksplorasi Kemampuan Pemecahan Masalah berdaarka Kategori Proses Literasi Matematis. Jurnal Pendidikan Matematika, 13(2), 163-184.

Osman, S., Yang, C. N. A. C., Abu, M. S., Ismail, N., Jambari, H., \& Kumar, J. A. (2018). Enhancing students' mathematical problem-solving skills through bar model visualisation technique. International Electronic Journal of Mathematics Education, 13(3), 273-279.

Prabawati, M. N. (2018). Analisis Kemampuan Literasi Matematik Mahasiswa Calon Guru Matematika. Mosharafa: Jurnal Pendidikan Matematika, 7(1), 113-120.

Rohmah, M., \& Sutiarso, S. (2018). Analysis problem solving in mathematical using theory Newman. Eurasia Journal of Mathematics, Science and Technology Education, 14(2), 671-681. https://doi.org/10.12973/ejmste/80630

Rusmining, R. (2017). Analysis of Mathematics Literacy of Students of Mathematics Education Department Viewed from Process Components. Unnes Journal of Mathematics Education, 6(3), 384-390. 
Scherer, R., \& Beckmann, J. F. (2014). The acquisition of problem solving competence: evidence from 41 countries that math and science education matters. Large-Scale Assessments in Education, 2(1), 1-22.

Schleicher, A. (2019). PISA 2018: Insights and Interpretations. OECD Publishing.

Stacey, K. (2011). The PISA View of Mathematical Literacy in Indonesia. Indonesian Mathematical Society Journal on Mathematics Education, 2(2), 95-126.

Sumirattana, S., Makanong, A., \& Thipkong, S. (2017). Using realistic mathematics education and the DAPIC problem-solving process to enhance secondary school students' mathematical literacy. Kasetsart Journal of Social Sciences, 38(3), 307-315.

Syawahid, M., \& Putrawangsa, S. (2017). Kemampuan literasi matematika siswa SMP ditinjau dari gaya belajar. Beta: Jurnal Tadris Matematika, 10(2), 222-240.

Tambychik, T., \& Meerah, T. S. M. (2010). Students' difficulties in mathematics problem-solving: What do they say? Procedia - Social and Behavioral Sciences, 8(5), 142-151. https://doi.org/10.1016/j.sbspro.2010.12.020

Umbara, U., \& Suryadi, D. (2019). Re-interpretation of mathematical literacy based on the teacher's perspective. International Journal of Instruction, 12(4), 789-806. https://doi.org/10.29333/iji.2019.12450a

Utami, R. W., \& Wutsqa, D. U. (2017). Analisis kemampuan pemecahan masalah matematika dan self-efficacy siswa SMP negeri di Kabupaten Ciamis. Jurnal Riset Pendidikan Matematika, 4(2), 166. https://doi.org/10.21831/jrpm.v4i2.14897

Van Merrienboer, J. J. G. (2013). Perspectives on problem solving and instruction. Computers \& Education, 64, 153-160.

Wijaya, A. (2016). Students' information literacy: A perspective from mathematical literacy. IndoMS Journal Mathematics Education, 7(2), 73-82.

Zahid, M. Z. (2020). Telaah kerangka kerja PISA 2021 : Era Integrasi Computational Thinking dalam Bidang Matematika. Prosiding Seminar Nasional Matematika, 3(March 2020), 706-713.

How to cite : Samosir, E., Makmuri., \& Aziz, T. A., 2022. Kemampuan Literasi Matematika: Kaitannya dengan Kemampuan Pemecahan Masalah. Jurnal Riset Pendidikan Matematika Jakarta. 4(1). 60-72. https://doi.org/10.21009/jrpmj.v4i1.23026

To link to this article: https://doi.org/10.21009/jrpmj.v4i1.23026 